\title{
Gender and Learners' Beliefs in Corrective Feedback in Learning Chinese as a Foreign Language: A Network Questionnaire Survey Report
}

\author{
Liqin $\mathrm{Wu}^{1}$ \\ ${ }^{1}$ Anhui University of Finance and Economics, Bengbu, Anhui, China \\ Correspondence: Liqin Wu, a professor of English in Languages and Media, AUFE. Her fields of interest include \\ SLA, applied linguistics, psycholinguistics, etc. 962 Caoshan Road, Bengbu, Anhui, China. 233030. E-mail: \\ lilywulq@126.com
}

Received: November 3, 2020; Accepted: November 13, 2020; Published: November 14, 2020

This research is financially supported by The Key Anhui Humanities and Social Sciences Planned Project Fund (AHSKZ2018D16); and by The Key Scientific Research Fund in Anhui University of Finance and Economics (AUFE) (ACKY1805ZDA).

\begin{abstract}
This network questionnaire survey aims to confirm whether gender differences exist in learners' beliefs in corrective feedback (CF) in learning Chinese as a foreign language (LCFL). Ninety-seven (53 male and 44 female) university learners of Chinese from 33 countries participated in the survey. The statistical results indicated that there were little significant differences in male and female learners' beliefs in CF in LCFL except in two psychological effects in which male learners seemed more emotional or grateful to teachers' correction; that culture did not influence male and female learners' beliefs in CF; that self-correction and teachers' correction are more welcomed than peers'; that immediate correction in specific contexts was preferred; that teachers were supposed to tell the learners where the mistake was before correcting it; that it was not confirmed whether direct or indirect correction was better; that learners' preference of frequency of CF was between sometimes or often; and that negative effects of CF were not found. These findings may contribute to the Chinese teachers' understanding of learners as individuals and to correction methods teachers adopt while confronting learners' errors in teaching Chinese as a foreign language (TCFL) classes.
\end{abstract}

Keywords: gender, beliefs, CF, LCFL, network questionnaire survey

\section{Introduction}

The difference between male and female is something that everybody knows and nobody knows (Money, 1987, 13). A long history of research has shown that females are superior on many measures of memory, verbal tasks without considering the types of memory, like episodic memory, and the quality of the speech (Halpern, 2012, 115-123). Numerous indicators of gender differences in second language acquisition (SLA) or foreign language learning (FLL) have been presented by scholars and researchers (Aliakbari \& Tazik, 2011; Ehrlich, 1997; Kobayashi, 2002; Tercanlioglu, 2004; Zoghi et al., 2013). And the relationship between learners' beliefs and the preference of CF has been studied (Ding \& Zhao, 2019; Zu \& Ma, 2015). Results display that teachers may not be aware of the students preferred CF types in written errors (Alshahrani \& Storch, 2013). The preference of CF type is closely related to anxiety. For example, recast and metalinguistic feedback types were better rated by the students who reported higher levels of anxiety in oral communication classes (Martin \& Valdivia, 2017).

However, research on gender and learners' beliefs in CF in LCFL is rarely reported. Do gender differences exist in learners' beliefs in CF in LCFL? This is a crucial issue in LCFL or TCFL that the author tries to explore to contribute to LCFL or to SLA.

\section{Literature Review}

Previous studies in gender and learners' beliefs in CF in SLA or FLL comprise two essential issues. One is about gender in SLA; the other concerns the relationship between the choice of CF types and learners' beliefs. 


\subsection{Gender in SLA}

Gender's role in SLA or FLL has been a controversial issue for researchers, educators, and scholars for over half a century. Earlier research in gender differences in SLA or FLL can be divided into two main streams: One features performance-related differences, learning strategy differences and language learning as being a particularly female activity; The other manifests more social constructionist views of language and gender (Feery, 2008). Gender differences are studied from the perspectives of sociolinguistics, ethnology, pedagogy, linguistics, psycholinguistics, and cognitive linguistics, etc.

Much evidence seems to have shown that females tend to have better verbal abilities than males, males are better than girls in mathematics. Bećirović's (2017) findings indicate that female students are more successful at learning English as a foreign language than male students at each group/grade level. But females' advantage in verbal abilities is likely to be small and depends on the type of verbal ability that is measured (Halpern, 2012, 119). And their language proficiency is a genetically-influenced ability interacting with environmental factors such as motivation, orientation, education, and learner strategies that still mediate between endowment and acquiring language proficiency at an adult stage (van der Slik et al., 2015).

Hyde et al. (2008) research in several states in the United States indicates that there was virtually no difference in the average math scores for girls and boys from Grades 2 through 11. But, as the authors noted, the items in the tests required lower level thinking rather than higher level thinking. Besides, races play a dominant role in the significance of sex differences in mathematics at advanced level. For White students, predominance of boys to girls among the highest scorers was obvious, but it was vague for Asian/ Pacific Islander students (Halpern, 2012, 146).

Karlak \& Medve's (2016) research reveals that female learners were significantly more motivated than males in certain motivational dimensions, but male learners of English achieved statistically significantly higher results than female peers in standardized evaluation. However, in German no statistically significant gender differences were found, irrespective of the measure of communicative competence.

Besides, males and females are proven to be different in cognitive styles or psychological differentiation (Witkin et al., 1962; Kao et al., 2017). Evidence suggests that girls were better at recognizing faces than boys (Rehman \& Herlitz, 2006; Sasson et al, 2010). Regarding the interaction of age with gender, females consistently outperformed males in the reported strategy use, in all grade levels and categories except for the social (Platsidou \& Sipitanou, 2015). Females were found to be more motivated than male language learners, and have more positive attitudes toward speakers of the target language (Gardner and Lambert, 1972; Muchnick and Wolfe, 1982). On the other hand, in the research on the gender differences in affective variable in FLL, females showed higher anxiety than males though they earned higher scores on exams (Bell \& McCallum, 2012). But it was also reported that boys, but not girls, used negative attributes for self-description (Martínez-Marín, 2019). Kriegbaum et el's (2018) study found no significant moderator effects for gender. Males and females exhibited different advantages and disadvantages in learning online within the personal learning environment (Wu \& Cheng, 2019).

\subsection{CF and Language Learner Beliefs in SLA or FLL}

$\mathrm{CF}$ refers to "any indication to the learners that their use of language is incorrect, including various responses that learners receive" (Lightbown and Spada, 1999, 171-172). In a narrow sense, CF was usually categorized into six types (Lyster \& Ranta, 1997), including explicit correction, recasts, clarification requests, metalinguistic feedback, elicitation, and repetition. But in a broad sense, it takes two forms: explicit and implicit or direct and indirect (Ellis et al., 2009; Karim \& Nassaji, 2020; Kim et al., 2020; Lyster et al., 2013).

Language learner beliefs in SLA or FLL were initially proposed and then were theoretically put forward by Horwitz $(1985 ; 1988)$ for the well-known Beliefs About Language Learning Inventory (BALLI). The current research on language learner beliefs in SLA or FLL often revolves around the following eight questions based on the early five ones (Ellis, 2009; Hendrickson, 1978; Zhu \& Wang, 2019): 1. Is it necessary for the teacher to correct learners' errors? 2. What errors should be corrected? Errors in spelling or grammar or pronunciation or reading aloud or structure, or any other errors? 3. Who is to correct the error? It is the teacher or the student himself or herself or the peers who should correct the errors? 4 . When to correct? Should errors be corrected immediately or afterwards? 5. How to correct? Should errors be corrected explicitly or implicitly (or directly or indirectly)? Or by using any or some of the six types mentioned above? 6. Which type of CF is the most effective? 7. How often is to correct? Always or often or sometimes or seldom correct? 8. What effects of CF produces on learners? Positive or negative effects? 
So far, the research on the gender and learners' beliefs in CF, especially in CF in LCFL is rarely reported. Therefore, it is of vital importance to conduct this research to fill the gap in this aspect.

This article is to compare male and female learners' beliefs in CF in LCFL with the aim to determine whether gender influences learners' beliefs in CF in LCFL to eliminate gender-based stereotypes in language learning. Moreover, it tries to uncover what male and female learners perceive about CF in LCFL and how they expect the teacher to correct their errors. It is hoped that the results of this study have some potential implications for teachers to improve teaching pedagogy in TCFL and considering learners as individuals instead of simply different gender groups.

\section{Research Questions and Hypotheses}

This article explores the relation between gender and learners' beliefs in CF in LCFL. The questions the author raises are:

1. Do male and female learners perceive CF differently in Chinese classes?

2. Do male and female learners anticipate different types of CF from their Chinese teachers?

3. Do cultural factors influence male and female learners' beliefs in CF in LCFL since they are from 33 different cultural backgrounds?

To answer the above questions, we pose the following hypotheses:

$\mathrm{H}_{1}$ : Male and female learners have similar perception of CF in LCFL.

$\mathrm{H}_{2}$ : Male and female learners have similar beliefs in CF in LCFL.

$\mathrm{H}_{3}$ : Culture influences male and female learners' beliefs in CF in LCFL.

\section{Methodology}

In this network questionnaire survey, the quantitative research was applied to discern whether gaps exist between male and female learners, hoping to find some constructive clues for LCFL or TCFL. A 5-point Likert scale was mainly used to measure students' beliefs in CF in LCFL.

\subsection{Participants}

Ninety-seven international students, including 53 males, 44 females, participated in this on-line survey. The participants had studied Chinese for 5 months to 5 years, a great majority of them were studying in different universities in Anhui Province in China. They were from 33 countries in Asia, Africa, Europe, island country of Southwest Pacific Ocean and South America.

\subsection{Instrument}

The network questionnaire survey on learners' beliefs in CF in LCFL is made up of three sections with 56 items in total. Section 1 was about demographic data, items 1-4 in this section were: gender, nationality, time of Chinese study, and the university where the participant was learning Chinese. Section 2 was composed of 47 items about learners' perception of committing verbal errors in Chinese classes, and eight issues in CF: whether, what, who, when, how, how often, which and what effects (including students' psychological effects CF produced in Chinese classes). The 5-point Likert scale used in items 5-47 was: $1=$ strongly disagree; $2=$ disagree; $3=$ not sure; $4=$ agree; $5=$ strongly agree; but the scale in items $48-51$ was: $1=$ never; $2=$ seldom; $3=$ sometimes; $4=$ often; $5=$ always since it was about the survey of the frequency of CF. After finishing reading each of the 47 items, participants were required to choose one choice from the 5-point Likert scale.

To know more about how and when to correct in in oral and written classes, Section 3 was designed, which included 5 questions. Different from those above, the choices in the section were more detailed and concrete. Choices in items 52-55 were: $1=$ immediately correct; $2=$ correct after I finish speaking; $3=$ correct me personally after class; $4=$ correct together with other peer' errors; $5=$ not correct. The choices for item 56 were: $1=$ correct together with peers'errors; $2=$ The teacher underlines the wrong places, then the students correct them by themselves; $3=$ give the correct forms directly; $4=$ correct face to face; $5=$ The teacher provides the related network link addresses, and then the students search for the relevant information themselves; $6=$ not to correct; $7=$ other methods.

To guarantee the quality of the questionnaire survey, the items of the same category were maximally separated; affirmative and negative items were alternated; and the same issue was asked occasionally twice in different ways to avoid the participants' inertial selection.

Wen juan xing (https://www.wjx.cn/), an online questionnaire survey platform in China was used in distributing, collecting and analyzing the questionnaire survey. The statistical technique employed for comparison 
and analysis in this platform was a paid on-line SPSS software through using one-way anova. It was used to calculate the mean of the male and the female learners' choices, and finally test if the observed data supported the hypotheses.

Gender was considered as the single independent variable, and all the other 52 items in Sections 2 and 3 as dependent variables.

\section{Data Collection and Analysis}

Learners were invited to complete the survey at we-chat without time limitation. After their submission, the data were automatically collected and calculated at wen juan xing. By using one-way anova, the results of learners' beliefs in CF in LCFL were obtained.

The following is about the results of one-way anova about male and female learners' beliefs in CF in LCFL in Section 2 (see Tables 1)

Table 1. One-Way ANOVA: Male and Female Learners' Beliefs in CF in LCFL (Section 2)

\begin{tabular}{|c|c|c|c|c|}
\hline \multirow{2}{*}{ Item } & \multicolumn{2}{|l|}{$\begin{array}{l}\text { Gender } \\
(\mathbf{M} \pm \text { SD })\end{array}$} & \multirow{2}{*}{$\mathbf{F}$} & \multirow{2}{*}{$\mathbf{p}$} \\
\hline & $\begin{array}{l}\text { Male } \\
(\mathbf{n}=53)\end{array}$ & $\begin{array}{l}\text { Female } \\
(\mathrm{n}=\mathbf{4 4})\end{array}$ & & \\
\hline \multicolumn{5}{|l|}{ Perception of language errors } \\
\hline 9. It is normal for me to commit errors in the process of Chinese learning. & $4.21 \pm 0.77$ & $4.27 \pm 0.76$ & 0.175 & 0.677 \\
\hline \multicolumn{5}{|l|}{ Whether to Correct } \\
\hline 5. It is very necessary for teachers to correct students' language errors. & $4.11 \pm 0.70$ & $4.32 \pm 0.67$ & 2.139 & 0.147 \\
\hline 28. Teachers should correct students' language errors in class. & $4.04 \pm 0.71$ & $4.11 \pm 0.75$ & 0.261 & 0.610 \\
\hline 31. I don't like teachers to correct my errors in class. & $1.94 \pm 1.08$ & $2.07 \pm 1.02$ & 0.337 & 0.563 \\
\hline \multicolumn{5}{|l|}{ What to Correct } \\
\hline 6. Errors in oral Chinese practice class should be corrected. & $4.11 \pm 0.91$ & $4.18 \pm 0.69$ & 0.168 & 0.683 \\
\hline 11. I hope the teacher will correct every mistake I make. & $3.72 \pm 1.01$ & $4.07 \pm 0.93$ & 3.146 & 0.079 \\
\hline 35. I would like my teachers to correct my oral errors. & $4.15 \pm 0.60$ & $4.14 \pm 0.80$ & 0.011 & 0.918 \\
\hline 36. I would like my teacher to correct my written errors. & $4.26 \pm 0.59$ & $4.34 \pm 0.75$ & 0.319 & 0.574 \\
\hline 40. Teachers should try to correct all the students' language errors. & $3.92 \pm 0.90$ & $3.77 \pm 1.01$ & 0.616 & 0.434 \\
\hline $\begin{array}{l}\text { 41. Teachers should correct the common or habitual errors, not all of } \\
\text { them. }\end{array}$ & $3.36 \pm 0.92$ & $3.39 \pm 0.99$ & 0.020 & 0.886 \\
\hline 42. Teachers should focus on correcting grammatical errors. & $3.36 \pm 0.94$ & $3.41 \pm 1.00$ & 0.066 & 0.798 \\
\hline $\begin{array}{l}\text { 32. Teachers should not correct students' pronunciation errors in class } \\
\text { unless they interfere with comprehensibility. }\end{array}$ & $2.19 \pm 1.08$ & $2.25 \pm 1.16$ & 0.073 & 0.788 \\
\hline $\begin{array}{l}\text { 33. Teachers should not correct students' grammatical errors in class } \\
\text { unless they interfere with comprehensibility. }\end{array}$ & $2.26 \pm 1.09$ & $2.27 \pm 1.11$ & 0.001 & 0.970 \\
\hline \multicolumn{5}{|l|}{ Who is to correct } \\
\hline $\begin{array}{l}\text { 29. Students' language errors should be corrected by teachers because } \\
\text { they are specialists. }\end{array}$ & $3.89 \pm 1.01$ & $4.16 \pm 0.71$ & 2.252 & 0.137 \\
\hline $\begin{array}{l}\text { 14. When I commit language errors in class, I hope the teacher will guide } \\
\text { me to find the correct form myself. }\end{array}$ & $4.09 \pm 0.74$ & $4.27 \pm 0.62$ & 1.606 & 0.208 \\
\hline $\begin{array}{l}\text { 30. It is better for teachers to guide students to correct their errors by } \\
\text { themselves than to say the correct forms directly. }\end{array}$ & $3.74 \pm 1.06$ & $3.75 \pm 0.84$ & 0.005 & 0.943 \\
\hline $\begin{array}{l}\text { 37. I prefer to be corrected by my peers in a small group work rather than } \\
\text { by my teachers in front of the entire class. }\end{array}$ & $2.87 \pm 1.02$ & $2.73 \pm 1.02$ & 0.457 & 0.501 \\
\hline \multicolumn{5}{|l|}{ When to Correct } \\
\hline $\begin{array}{l}\text { 10. In my view, the teacher should correct my errors immediately in } \\
\text { class. }\end{array}$ & $3.94 \pm 0.72$ & $3.93 \pm 0.79$ & 0.006 & 0.94 \\
\hline $\begin{array}{l}\text { 7. I hope the teacher can correct my errors immediately when I commit } \\
\text { errors in answering questions. }\end{array}$ & $4.06 \pm 0.84$ & $3.89 \pm 1.02$ & 0.815 & 0.369 \\
\hline
\end{tabular}




\begin{tabular}{|c|c|c|c|c|}
\hline $\begin{array}{l}\text { 8. I hope the teacher can correct my errors immediately when I commit } \\
\text { errors in reading the text aloud. }\end{array}$ & $4.04 \pm 0.92$ & $3.91 \pm 0.77$ & 0.543 & 0.463 \\
\hline $\begin{array}{l}\text { 16. I hope the teacher will correct my errors immediately when I make } \\
\text { errors in pronunciations. }\end{array}$ & $4.15 \pm 0.69$ & $4.30 \pm 0.59$ & 1.194 & 0.277 \\
\hline $\begin{array}{l}\text { 17. I hope the teacher will correct my errors immediately when I make } \\
\text { errors in vocabulary. }\end{array}$ & $4.04 \pm 0.78$ & $4.11 \pm 0.62$ & 0.272 & 0.603 \\
\hline $\begin{array}{l}\text { 18. I hope the teacher will correct my errors immediately when I make } \\
\text { errors in grammar. }\end{array}$ & $4.13 \pm 0.79$ & $4.14 \pm 0.73$ & 0.001 & 0.978 \\
\hline $\begin{array}{l}\text { 19. I hope the teacher will correct my errors immediately when I make } \\
\text { errors in language use. }\end{array}$ & $4.06 \pm 0.74$ & $4.18 \pm 0.58$ & 0.826 & 0.366 \\
\hline $\begin{array}{l}\text { 43. When a student makes an error, the teacher had better correct it } \\
\text { immediately. }\end{array}$ & & $3.77 \pm 0.89$ & 0.000 & 0.996 \\
\hline \multicolumn{5}{|l|}{ How to Correct } \\
\hline $\begin{array}{l}\text { 12. When I commit language errors in class, I hope the teacher will tell } \\
\text { me directly the correct form. }\end{array}$ & 3.9 & $4.11 \pm 0.69$ & 1.797 & 0.183 \\
\hline $\begin{array}{l}\text { 13. When I commit language errors in class, I hope the teacher will tell } \\
\text { me what is wrong before telling me the correct form. }\end{array}$ & $4.15 \pm 0.69$ & $4.25 \pm 0.75$ & 0.457 & 0.501 \\
\hline $\begin{array}{l}\text { 44. When a student makes a mistake, the best strategy is to say clearly, } \\
\text { "No, you should not say in this way, you should say...". }\end{array}$ & $3.51 \pm 1.05$ & $3.50 \pm 1.17$ & 0.002 & 0.967 \\
\hline $\begin{array}{l}\text { 45. When students make errors, the best strategy is to explain the relevant } \\
\text { grammar rules. }\end{array}$ & $3.96 \pm 0.78$ & $4.05 \pm 0.68$ & 0.305 & 0.582 \\
\hline \multicolumn{5}{|l|}{ How often to correct } \\
\hline 48. Teachers should ( ) correct pronunciation errors. & $3.91 \pm 0.95$ & $4.05 \pm 0.78$ & 0.616 & 0.434 \\
\hline 49. Teachers should ( ) correct lexical errors. & $3.83 \pm 0.96$ & $3.91 \pm 0.86$ & 0.180 & 0.673 \\
\hline 50. Teachers should ( ) correct grammar errors. & $3.98 \pm 0.97$ & $4.20 \pm 0.77$ & 1.538 & 0.218 \\
\hline 51. Teachers should ( ) correct language use errors. & $3.92 \pm 1.00$ & $4.11 \pm 0.84$ & 0.994 & 0.321 \\
\hline \multicolumn{5}{|l|}{ Which is effective } \\
\hline $\begin{array}{l}\text { 46. Indirect error correction is better than direct one because it does not } \\
\text { hurt students' self-esteem. }\end{array}$ & $3.49 \pm 1.05$ & $3.36 \pm 1.16$ & 0.319 & 0.574 \\
\hline $\begin{array}{l}\text { 47. Direct error correction is often more effective than indirect one } \\
\text { because it saves students' time to find out the correct one. }\end{array}$ & & $3.77 \pm 0.96$ & 2.690 & 0.104 \\
\hline \multicolumn{5}{|l|}{ What Effects of CF } \\
\hline $\begin{array}{l}\text { 15. It helps me a lot when the teacher corrects my language errors in } \\
\text { class. }\end{array}$ & 4.3 & $4.25 \pm 0.53$ & 0.481 & 0.490 \\
\hline $\begin{array}{l}\text { 38. I learn a lot when my teacher corrects the errors made by my peers } \\
\text { in class. }\end{array}$ & $3.96 \pm 0.88$ & $3.89 \pm 0.89$ & 0.177 & 0.675 \\
\hline 39. I learn a lot when my teacher corrects the errors I make in class. & $4.15 \pm 0.74$ & $4.14 \pm 0.77$ & 0.009 & 0.925 \\
\hline 20. If the teacher keeps correcting me, I will be unwilling to speak. & $2.38 \pm 1.18$ & $2.23 \pm 1.22$ & 0.378 & 0.540 \\
\hline 21. If the teacher keeps correcting me, I will be afraid to speak. & $1.89 \pm 0.95$ & $2.11 \pm 1.17$ & 1.111 & 0.294 \\
\hline 22. Teachers' correction makes me feel humiliated. & $1.96 \pm 1.14$ & $1.80 \pm 0.98$ & 0.583 & 0.447 \\
\hline 23. Teachers' correction in class makes me nervous and anxious. & $1.83 \pm 1.01$ & $2.02 \pm 1.07$ & 0.826 & 0.366 \\
\hline 24. Teachers' correction in class makes me shy. & $1.89 \pm 1.01$ & $2.14 \pm 1.15$ & 1.287 & 0.259 \\
\hline $\begin{array}{l}\text { 25. Teachers' correction in class makes me reluctant to answer the } \\
\text { questions for a period. }\end{array}$ & 2.0 & $1.95 \pm 0.99$ & 0.085 & 0.771 \\
\hline 26. I feel lucky when my teacher corrects my errors in class. & $3.87 \pm 1.16$ & $3.27 \pm 1.39$ & 5.295 & $0.024 *$ \\
\hline 27. I feel grateful to my teacher for correcting my errors. & $4.17 \pm 0.94$ & $3.52 \pm 1.41$ & 7.331 & $0.008^{* *}$ \\
\hline 34. I feel cheated if a teacher does not correct the written work I hand in. & $3.30 \pm 0.99$ & $3.59 \pm 1.02$ & 1.991 & 0.161 \\
\hline
\end{tabular}

Results indicate that statistically significant differences were not found between gender and perception of committing verbal errors in Chinese classes and eight issues ( $\mathrm{p}>0.05)$ except in items 26 and $27(* \mathrm{p}<0.05$; ** $\mathrm{p}<0.01)$. 
The mean in each item in Tables 1 demonstrates that male and female learners showed little difference in perception of committing language errors. Concisely, both male and female learners agreed or quite agreed to the normality to commit errors in the process of Chinese learning and necessity to correct errors (whether to correct). They showed little difference in what to correct, too. Specifically, they agreed to or strongly agreed to error correction in oral Chinese practice class. As to whether every mistake or common/habitual or grammar mistakes should be corrected, their choices were between not sure and agree. However, they agreed or strongly agreed to oral and written correction. Regarding the items whether pronunciation or grammatical errors in class should not be corrected if they do not interfere with comprehensibility, their choices were close to disagree. Concerning who is to correct, their choices were also similar to each other. If we arrange them from strongly agree to strongly disagree, they are self-correction under guidance (but learners hesitated when teachers' correction and selfcorrection were mixed), teachers' correction, and peers' correction. Likewise, they were consistent with each other in when to correct. Specifically, both male and female learners agreed or strongly agreed to immediate correction of errors in pronunciation, vocabulary, grammar and language use. As to immediate correction of errors in answering questions, reading the text aloud, males $(4.06 ; 4.04)$ showed a little bit stronger desire than females $(3.89 ; 3.91)$. But for the general statement of immediate correction of errors(items 10 and 13), the means were lower than those for the concrete ones(items 7, 8, 16, 17, 18 and 19). Equally, they displayed little discrepancy in how to correct. They agreed or strongly agreed to the statement of telling students what is wrong before telling them the correct form. The means of the females in telling directly the correct form (4.11) and explaining the relevant grammar rules $(4.05)$ were a bit higher than those of the males $(3.91 ; 3.96)$. They showed no certainty in direct correction "No, you should not say in this way, you should say...". Male and female learners didn't show any significant differences in how often to correct, either. Their means were approximately between sometimes and often whether it was in pronunciation, lexical, grammar or language use errors, with female learners' means $(4.05 ; 3.91 ; 4.20 ; 4.11)$ respectively a bit higher than male learners' $(3.91 ; 3.83 ; 3.98 ; 3.92)$. Moreover, they demonstrated little differentia in which type of $C F$ is most effective. Detailly, it was not obvious as whether direct or indirect correction is better, for all their means were below 4 . They also showed little difference in the effects of $C F$ except in except in items 26 and 27. Specifically, significant gender difference existed in "I feel lucky when my teachers correct my errors in class" for its $p$ was less than $0.05(\mathrm{~F}=5.295, \mathrm{p}=0.024)$. The mean of the male in this item was 3.87, obviously higher than that of the female (3.27). Great significant gender difference also appeared in "I feel grateful to my teacher for correcting my errors" for its $p$ was less than $0.01(\mathrm{~F}=7.331, \mathrm{p}=0.008)$. And the mean of the male in this item was 4.17, obviously higher than that of the female (3.52). Overall, they agreed to or strongly agreed to the positive effect of CF provided by teachers. But the effect of peers' correction was not as apparent as that of teachers'. The positive psychological effects were also revealed from the means. Teachers' CF did not make learners unwilling to speak, afraid to speak, feel humiliated, nervous and anxious, or reluctant to answer the questions for a period. But it was not certain whether learners would feel cheated without teachers' $\mathrm{CF}$.

Then, the form of the questionnaire was transformed into 5 questions to know more about how and when to correct in oral and written classes. Here are the results of one-way anova about male and female learners' beliefs in CF in LCFL in Section 3 (see Tables 2).

Table 2. One-Way ANOVA: Male and Female Learners Beliefs in CF in LCFL (Section 3)

\begin{tabular}{|c|c|c|c|c|}
\hline \multirow{2}{*}{$\begin{array}{l}\text { Item } \\
\text { Answer the following questions. }\end{array}$} & \multicolumn{2}{|c|}{ Gender $(\mathrm{M} \pm \mathrm{SD})$} & \multirow{2}{*}{$\mathbf{F}$} & \multirow[b]{2}{*}{$\mathbf{p}$} \\
\hline & Male $(n=53)$ & Female $(n=44)$ & & \\
\hline \multicolumn{5}{|l|}{ When and how to correct } \\
\hline $\begin{array}{l}\text { 52. When do you expect the teacher to correct your pronunciation } \\
\text { errors in oral practice class? }\end{array}$ & $2.09 \pm 1.13$ & $2.05 \pm 0.94$ & 0.052 & 0.820 \\
\hline $\begin{array}{l}\text { 53. When do you expect the teacher to correct your lexical errors in } \\
\text { oral practice class? }\end{array}$ & $2.04 \pm 1.04$ & $1.98 \pm 0.82$ & 0.098 & 0.755 \\
\hline $\begin{array}{l}54 \text {. When do you expect the teacher to correct your grammar errors } \\
\text { in oral practice class? }\end{array}$ & $2.21 \pm 1.12$ & $2.20 \pm 1.02$ & 0.000 & 0.989 \\
\hline $\begin{array}{l}\text { 55. When do you expect the teacher to correct your language use } \\
\text { errors in oral practice class? }\end{array}$ & $2.04 \pm 1.04$ & $2.05 \pm 0.91$ & 0.001 & 0.969 \\
\hline $\begin{array}{l}\text { 56. In what way do you like your teacher to correct your written } \\
\text { mistakes? }\end{array}$ & $2.68 \pm 1.65$ & $2.11 \pm 1.35$ & 3.321 & 0.072 \\
\hline
\end{tabular}

$* \mathrm{p}<0.05, * * \mathrm{p}<0.01$ 
As the table reveals that male and female learners did not display any significant differences in when and how to correct in oral and written courses, either ( $p>0.05$ ). Their choices in items 52-55 mainly focused on correction after finishing speaking in oral practice class. As to the written errors, their choices were between underlining the wrong places for students to correct them by themselves and teacher's giving the correct forms directly.

\section{Discussion}

Both male and female learners demonstrated little significant differences in perception of committing verbal errors in Chinese classes, and in whether, what, who, when, how, how often, which and what effects in CF in LCFL. These results accept $\mathrm{H}_{1}$ and $\mathrm{H}_{2}$ except in items 26 and 27. Male learners showed more gratefulness and sensitivity to teachers' CF than female ones, which is quite beyond the traditional images of males who are masculine and insensitive to emotions. A further research has found that "The human male is, on most measures, more vulnerable than the female. Part of the explanation is the biological fragility of the male fetus, which is little understood and not widely known."(Kraemer, 2000) It is the biological factor that partially accounts for the emotional gap between male and female learners. Therefore, masculine stereotype on males is harmful to learners and teachers. This finding enables the author to stand firm on the belief that males, like females, are individuals with similarities and differences.

However, the results do not accept $\mathrm{H}_{3}$, i.e. culture did not categorize these international learners into male or female group with different beliefs in CF in LCFL although they were from 33 cultural backgrounds with diverse educational customs. In other word, male and female learners' beliefs are not influenced by their cultures.

\section{Limitations and Suggestions for Future Research}

This paper compared male and female learners' beliefs in CF in LCFL by means of one-way anova. The results found in the research may be conducive to LCFL or TCFL. Yet, limitations in the research constrained the researcher from going into the deeper side of the topic.

Firstly, all the results in this survey were based on a network questionnaire survey without other any parameters like interviews, learners' achievements, etc. Next, the 5-point Likert scale remained unaltered without flexible options that learners may choose from. Finally, the reasons for the choices were not supplied in the questionnaire survey. As a result, it is hard for the author to analyze the reasons when differences emerge.

Multiple research methods might be adopted for future research in the similar topics, case studies, ethnographic studies, narrative inquiry, etc. They may involve more detailed designs in each specific category to explore gender and learners' beliefs in CF in LCFL.

\section{Conclusion}

Results in one-way anova reveal that broadly there were little significant differences between male and female learners in CF in LCFL. These results echo the findings in Halpern (2012). The author compared male and female beliefs in CF in LCFL, she did not mean to distinguish males from females in learning. But rather she treated them equally or as a single group with different emotions and motivations in LCFL.

For a long time there has been existing a serious and common misunderstanding about sex differences: women are like this, men are like that, then treat each sex differently according to these differences. As a result, many similarities between males and females are obscured, and people as individuals are neglected (Halpern, 2012, 151). However, in modern scientific research every learner is an individual with individualized character, verbal ability, aptitude.

\section{Acknowledgements}

The author is very grateful to all the participants and teachers who have contributed a lot to the data collection.

\section{References}

Aliakbari, M., \& Tazik, K. (2011). On the relationship between gender and perceptual language learning styles: the case of Iranian academic EFL learners. Educational Psychology: An International Journal of Experimental Educational Psychology, 31(6), 654-674, https://doi.org/10.1080/01443410.2011.592275

Alshahrani, A., \& Storch, N. (2013). Investigating teachers' written corrective feedback practices in a Saudi EFL context: How do they align with their Beliefs, institutional guidelines, and students' preferences? Australian Review of Applied Linguistics, 37(2), 101-122. http://doi.org/10.1075/ARAL.37.2.02ALS

Bećirović, S. (2017). The Relationship between gender, motivation and achievement in learning English as a foreign language. European Journal of Contemporary Education, 6(2), 210-220. https://doi.org/10.13187/ejced.2017.2.210 
Bell, S., \& McCallum, R. (2012). Do foreign language learning, cognitive, and affective variables differ as a function of exceptionality status and gender? International Education, 42(1), 86-106. Retrieved from $\mathrm{http} / / /$ trace.tennessee.edu/internationaleducation/vol42/iss $1 / 6$

Ding,Y., \& Zhao. T. (2019). Chinese university EFL teachers' and students' beliefs about EFL writing: differences, influences, and pedagogical implications. Chinese Journal of Applied Linguistics, 42(2), 163-181. http://doi.org/10.1515/CJAL-2019-0010

Ehrlich, S. (1997). Gender as Social Practice: Implications for Second Language Acquisition. Studies in Second Language Acquisition, 19(4), 421-446. https://doi.org/10.1017/S0272263197004014

Ellis, R. (2009). Corrective feedback and teacher development, L2 Journal, 1, 3-18. http://doi.org/10.5070/12.v1i1.9054

Ellis, R., Loewen, S., \& Erlam, R. (2009). Implicit and explicit knowledge in second language learning, testing and teaching. Clevedon, North Somerset: United Kingdom: Multilingual Matters.

Feery, K. (2008). Current perspectives on the role of gender in Second Language Acquisition (SLA) Research. ITB Journal, 9(1), 32-51. https://doi.org/10.21427/D7DB3H

Gardner, R. C., \& Lambert, W. E. (1972). Attitudes and Motivation in Second Language Learning. Rowley, MA: Newbury House Publishers.

Halpern, D. F. (2012). Sex Differences in Cognitive Abilities. New York, NY: Psychology Press; Hove, East Sussex: Psychology Press.

Hendrickson, J. M. (1978). Error correction in foreign language teaching: Recent theory, research, and practice. Modern Language Journal, 62(8), 387-398. https://doi.org/10.1111/j.1540-4781.1978.tb02409.x

Horwitz, E. K. (1985). Using student beliefs about language learning and teaching in the foreign language methods course. Foreign Language Annals, 18, 333-340. https://doi.org/10.1111/j.1944-9720.1985.tb01811.x

Horwitz, E. K. (1988). The beliefs about language learning of beginning university foreign language students. Modern Language Journal, 72(3), 283-294. https://doi.org/10.1111/j.1540-4781.1988.tb04190.x

Hyde, J. S., Lindberg, S. M., Linn, M. C., Ellis, A., \& Williams, C. ( 2008 ). Gender similarities characterize math performance. Science, 321, 494-495. https://doi.org/10.1126/ science.1160364

Kao, P. C., Chen, K. T. C., \& Craigie, P. (2017). Gender differences in strategies for coping with foreign language learning anxiety. Social Behavior and Personality, 45(2), 205-210. https://doi.org/10.2224/sbp.5771

Karim, K., \& Nassaji, H. (2020). The revision and transfer effects of direct and indirect comprehensive corrective feedback on ESL students' writing. Language Teaching Research, 24(4), 519-539. https://doi.org/10.1177/1362168818802469

Karlak, M., \& Medve, V. B. (2016). Gender differences in the use of learning strategies, motivation and communicative competence in German and English as foreign languages. STRANI JEZICI, 45, 163-183. Retrieved from: https://hrcak.srce.hr/193101

Kim, Y. J., Choi, B., Kang, S., Kim, B., \& Yun, H. (2020). Comparing the effects of direct and indirect synchronous written corrective feedback: Learning outcomes and students' perceptions. Foreign Language Annals, 53(1), 176-199. http://doi.org/10.1111/flan.12443

Kobayashi , Y. (2002).The role of gender in foreign language learning attitudes: Japanese female students' attitudes towards English learning. Gender and Education, 14(2), 181-197. http://doi.org/10.1080/09540250220133021

Kraemer, S. (2000). The fragile male. BMJ, 321(7276): 1609-1612. https://doi.org/10.1136/bmj.321.7276.1609

Kriegbaum, K., Becker, B., \& Spinath, B. (2018). The relative importance of intelligence and motivation as predictors of school achievement: A meta-analysis. Educational Research Review, 25, 120-148. https://doi.org/10.1016/j.edurev.2018.10.001

Lightbown, P. M., \& Spada, N. (1999). How languages are learned. Oxford, UK. Oxford University Press.

Lyster, R., \& Ranta, L. (1997). Corrective feedback and learner uptake. Studies in Second Language Acquisition, 19, 37-66. https://doi.org/10.1017/S0272263197001034

Lyster, R., Saito, K., \& Sato, M. (2013). Oral corrective feedback in second language classrooms. Language Teaching, 46(1), 1-40. https://doi.org/10.1017/S0261444812000365 
Martínez-Marín, M.D., \& Martínez, C. (2019). Negative and positive attributes of gender stereotypes and gender self-attributions: A Study with Spanish adolescents. Child Indicators Research, 12, 1043-1063. https://doi.org/10.1007/s12187-018-9569-9

Martin, S., \& Valdivia, I. M. A. (2017). Students' feedback beliefs and anxiety in online foreign language oral tasks. International Journal of Educational Technology in Higher Education, 14(1), 1-15. http://doi.org/10.1186/s41239-017-0056-z

Money, J. (1987). Propaedutics of ducious G-I/R: Theoretical foundations for understanding dimorphic genderidentity/role. In J. M. Reinisch, L. A. Rosenblum, \& S. A. Sanders (Eds.), Masculinity/femininity: Basic perspectives. New York: Oxford, 13.

Muchnick, A. G., \& Wolfe, D. E. (1982). Attitudes and motivations of American students of Spanish. Canadian Modern Language Review, 38(2), 262-281. Retrieved from: https://eric.ed.gov/?id=EJ259797

Platsidou, M., \& Sipitanou, A. A. (2015). Exploring relationships with grade level, gender and language proficiency in the foreign language learning strategy use of children and early adolescents. International Journal of Research Studies in Language Learning, 4(1), 83-96. https://doi.org/10.5861/ijrsll.2014.778

Rehman, J. , \& Herlitz, A. ( 2006 ). Women remember more faces than men do. Acta Psychologica, 124, 344-355. https://doi.org/10.1016/j.actpsy.2006.04.004

Sasson, N. J., Pinkham, A. E., Richard, J., Hughett, P., Gur, R. E., \& Gur, R. C. (2010). Controllingfor response biases clarifies sex and age differences in facial affect recognition. Journal of Nonverbal Behavior, 34, $207-$ 221. http://doi.org/10.1007/s10919-0100092-z/

Tercanlioglu, L. (2004). Exploring gender effect on adult foreign language learning strategies. Issues in Educational Research, 14, 1-11. Retrieved from http://www.iier.org.au/iier14/tercanlioglu.html

van der Slik, F. W. P., van Hout, R. W. N. M., \& Schepens, J. J. (2015). The gender gap in second language acquisition: Gender differences in the acquisition of Dutch among immigrants from 88 countries with 49 mother tongues. PLOS ONE, 10(11), 1-22. https://doi.org/10.1371/journal. pone.0142056

Witkin, H. A., Dyk, R. B., Faterson, H. F., Goodenough, D. R., \& Karp, S. A. (1962). Psychological Differentiation. New York: Wiley and Sons.

$\mathrm{Wu}$, J. Y., \& Cheng, T. Y. (2019). Who is better adapted in learning online within the personal learning environment? Relating gender differences in cognitive attention networks to digital distraction. Computers \& Education, 128, 312-329. https://doi.org/10.1016/j.compedu.2018.08.016

Zhu, Y., \& Wang, B. L. (2019). Investigating English language learners' beliefs about oral corrective feedback at Chinese Universities: A large-scale survey, Language Awareness, 28(2), 139-161. https://doi.org/10.1080/09658416.2019.1620755

Zoghi, M., Kazemi, S. A., \& Kalani, A. (2013). The effect of gender on language learning. Journal of Novel Applied Sciences, 2(S4), 1124-1128. Retrieved from: http://jnasci.org/special-4/

$\mathrm{Zu}, \mathrm{X} . \mathrm{M} .$, \& Ma, Jiali (2015). Chinese teachers and students beliefs and attitudes regarding corrective feedback. Chinese Language Learning, 4, 66-75. Retrieved from http://en.cnki.com.cn/Article_en/CJFDTOTALHYXX201504008.htm

\section{Copyrights}

Copyright for this article is retained by the author(s), with first publication rights granted to the journal.

This is an open-access article distributed under the terms and conditions of the Creative Commons Attribution license (http://creativecommons.org/licenses/by/4.0/). 